RESENHA

\title{
O que é história do conhecimento?
}

\author{
Romélia Mara Alves Souto'
}

BURKE, Peter. O que é história do conhecimento? Tradução de Cláudia Freire. São Paulo: Editora UNESP, 2016. $211 p$.

\begin{abstract}
Assim como o livro, os intelectuais, as ciências e as culturas, também os processos de produção, armazenamento e disseminação de conhecimentos têm uma história. Esse tema, que já interessava a psicólogos, antropólogos e sociólogos, passou, desde os anos de 1990, a ocupar o centro de interesse de historiadores. A história do conhecimento, hoje institucionalizada como disciplina, desenvolveu-se como consequência da história da cultura, do livro e de outros tipos de história, mas principalmente da história dos intelectuais e da história da ciência. Peter Burke, um dos grandes historiadores de nosso tempo, presta sua relevante contribuição acerca desse tema com o livro $O$ que é história do con hecimento?, publicado em 2015 pela Universidade de Cambridge, Inglaterra, e no Brasil, em 2016, pela Editora UNESP. Depois de abordar a história do conhecimento nos últimos quinhentos anos em Uma história social do conbecimento: de Gutenberg a Diderot (2000) e Uma história social do conhecimento: da enciclopédia à Wikipédia (2012), Burke retorna com uma brilhante exposição das origens e dos fundamentos desse novo domínio da ciência histórica, distinguindo-o da história da ciência e da história dos intelectuais. Propondo um alargamento do campo da história da ciência, Burke argumenta que não existe história do conhecimento, existem apenas histórias, no plural, de conhecimentos, também no plural. Ao refletir sobre o que chama de movimento universal do "aprendizado coletivo", o autor elabora conceitos fundamentais para elucidar os processos de criação, armazenamento e difusão do conhecimento. Ao longo do texto, Burke apresenta uma variada gama de exemplos de épocas e lugares para traçar o percurso das histórias dos conhecimentos, e as notas explicativas fornecem significativas sugestões de leituras complementares. O livro está organizado em quatro capítulos:

1. "Conhecimentos e suas histórias";

2. "Conceitos";

3. "Processos"; e

4. "Problemas e perspectivas".
\end{abstract}

'Universidade Federal de São João del-Rei, MG, Brasil. 
No primeiro capítulo, o autor traz uma historiografia do conhecimento, faz distinção entre "informação" e "conhecimento" e apresenta a história e seus "vizinhos". Lançando mão de uma metáfora para distinguir "informação", como algo relativamente cru, de "conhecimento", como algo que foi processado, "cozido", Burke propõe um conceito amplo de conhecimento para "abarcar tudo aquilo que os indivíduos e os grupos-alvos de seus estudos considerarem como conhecimento" (p. 19).

O interesse pela produção histórica e pelo seu oposto complementar, a retenção histórica, cujo foco são os registros intencionalmente omitidos ou eliminados, tem permitido estudos tanto da memória quanto do esquecimento. No bojo desse movimento, Burke contempla a diversidade das histórias dos conhecimentos, destacando até mesmo a importância dos estudos da ignorância, do conhecimento que foi perdido ou conscientemente refutado. Ainda nesse capítulo, o autor adverte sobre a necessidade de evitar o "paroquialismo", no que diz respeito a espaço — que estabelece uma clara divisão entre Nós e Eles e todos os demais; e no que diz respeito a tempo - um simples contraste entre a Nossa Era e todo um passado sem distinções. Por essa perspectiva, faz mais sentido aos interessados pelos percursos da humanidade em seu longo aprendizado partir da história da ciência para a história mais ampla dos conhecimentos. De fato, não se pode utilizar genericamente o termo "ciência", que na acepção atual foi cunhado no século XIX, sem incorrer em um anacronismo. Burke destaca ainda outros fatores que ajudaram a impulsionar a guinada para a história do conhecimento com base na história da ciência: o surgimento do interesse acadêmico na cultura popular, permitindo incluir os conhecimentos práticos de outros sujeitos, o fato de que os métodos ditos científicos muitas vezes se desenvolveram fundamentados em práticas cotidianas menos formais e a crescente necessidade de discutir as conquistas intelectuais das culturas não ocidentais como contribuições ao conhecimento.

O segundo capítulo trata de um conjunto de termos úteis para elucidar os processos que permitem transformar informação em conhecimento, tais como conhecimentos localizados e conhecimentos subjugados, gestão do conhecimento, práticas, sistemas de ignorância, sociedade do conhecimento e cientificação. Destacaremos aqui um conceito-chave tratado nesse capítulo: as "ordens de conhecimento", definidas geralmente por lugar (por exemplo, ocidental, islâmico) ou por período (por exemplo, medieval, moderno). As formas e as instituições de conhecimento, assim como as interações entre elas associadas aos valores da cultura, constituem uma ordem ou sistema: escolas, universidades, arquivos, laboratórios, museus, redações de jornal, entre outros. Para exemplificar, Burke cita o sistema dominado pelo confucionismo e pelos concursos públicos na China tradicional; ou o sistema dominado pelo Islã, no Império Otomano; ou ainda, na União Soviética, onde o sistema era dominado pelo marxismo e pela Academia de Ciências. Assim, o sistema de conhecimento é percebido como algo atrelado a determinado tempo, lugar e comunidade, embora não seja impermeável e seja difícil falar em uma única ordem dominante. O conceito de ordem do conhecimento implica a consideração de seu oposto: o não conhecimento ou ignorância, que, no dizer do autor, refere-se àquilo que não é do conhecimento de diferentes tipos de povos em determinados lugares ou épocas. 
No terceiro capítulo são examinados os diferentes processos pelos quais passa a informação até ser transformada em conhecimento, para ser disseminado e utilizado em várias situações. Burke destaca, então, quatro estágios na sequência da obtenção ao uso da informação: coleta, análise, disseminação e utilização. No momento da coleta, o processo de "cozimento" já se iniciou, pois os princípios sob os quais se dá a seleção são culturalmente determinados. A coleta estende-se à observação, feita de questionamentos e de escutas. $\mathrm{O}$ advento da plataforma on-line provocou uma mudança drástica no modo como procuramos informações. $\mathrm{O}$ autor afirma a necessidade de uma "alfabetização em mecanismo de busca", dado que saber onde encontrar informações sobre determinado assunto é tão importante quanto o conhecimento do assunto. Já a análise consiste em transformar a informação em conhecimento por meio de práticas como descrição, quantificação, classificação e verificação. Ao tratar da disseminação do conhecimento, o autor discute o valor do testemunho oral, o problema relativo à variedade e ao caráter irreconciliável dos pontos de vista humanos e a transferência ou circulação do conhecimento, lembrando que o conhecimento recebido não é igual ao conhecimento emitido, em virtude de mal-entendidos, de adaptações deliberadas e de traduções culturais. Com sua aguda percepção e capacidade de delinear com clareza questões muito complexas, Burke conclui que, apesar da relevância das novas formas de comunicação, o meio mais eficaz de disseminação continua sendo o antigo, ou seja, o encontro com as pessoas - "as ideias circulam por aí dentro das pessoas" (p. 114).

O último capítulo do livro é dedicado aos problemas e perspectivas da história do conhecimento como área disciplinar. $\mathrm{O}$ autor examina questões relacionadas ao contraponto entre histórias internas e externas; continuidades e revoluções; agentes e sistemas; discutindo também questões de gênero, anacronismo, relativismo, triunfalismo e construtivismo. Consideramos importante destacar aqui o dilema vivido por historiadores dos conhecimentos por terem que escolher entre pressupor a superioridade da tradição científica ocidental ou tratar de forma igualitária todos os enfoques de conhecimento. No primeiro caso, são acusados de etnocentrismo. No segundo, de relativismo ou niilismo. Considerando que a maioria dos estudiosos do assunto escolheu a segunda opção, Burke concentra-se, então, na análise dos problemas decorrentes dessa escolha. Por fim, o autor apresenta suas perspectivas para as abordagens das histórias dos conhecimentos nas próximas décadas. Para ele, haverá uma tendência de se avançar dos estudos que tratam da difusão do conhecimento ocidental para os que tratam dos encontros, choques, traduções e hibridizações, caracterizando uma abordagem global. Haverá também uma guinada social focando uma história do conhecimento a partir das camadas inferiores com um crescente e já notório interesse nos conhecimentos cotidianos e tácitos. Finalmente, Burke acredita em uma tendência de ênfase nos estudos do conhecimento em longuíssimo prazo, na tentativa de responder à grande questão feita pelo historiador David Christian (2011): "Como esse acúmulo e compartilhamento de conhecimento geram as mudanças de longo prazo que distinguem a história dos seres humanos da história de espécies intimamente relacionadas?” 
Para terminar, Burke ainda apresenta uma cronologia selecionada de estudos do conhecimento e uma curta leitura complementar, na qual são mencionados alguns estudos acerca do conhecimento realizados em outras disciplinas que ele considera essenciais para os historiadores. Por fim, uma extensa lista de referências bibliográficas e um índice remissivo encerram esse belo trabalho que, a nosso ver, constitui uma importante contribuição e valiosa leitura a todos os interessados pelas histórias dos conhecimentos produzidos e disseminados pela humanidade em sua larga trajetória de aprendizado coletivo.

\section{REFERÊNCIAS}

Burke, P. Uma história social do conhecimento: de Gutenberg a Diderot. Tradução de Plínio Dentzien. Rio de Janeiro: Jorge Zahar Editor, 2003.

. Uma história social do conhecimento II: da enciclopédia à Wikipédia. Tradução de Denise Bottmann. Rio de Janeiro: Jorge Zahar Editor, 2012.

Christian, D. Maps of time: an introduction to big history. Berkeley: University of California Press, 2011.

\section{SOBRE A AUTORA}

Romélia Mara Alves Souto é doutora em educação matemática pela Universidade Estadual Paulista "Júlio de Mesquita Filho" (UNESP). Professora da Universidade Federal de São João del-Rei (UFSJ). E-mail:romelia@ufsj.edu.br 